\title{
Modelling Evapotranspiration to Increase the Accuracy of the Estimations Based on the Climatic Parameters
}

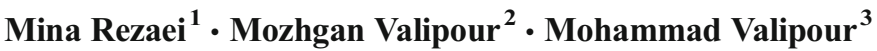

Received: 16 June 2016 /Revised: 19 September 2016 / Accepted: 20 September 2016 / Published online: 10 October 2016

(C) Springer Science+Business Media Singapore 2016

\begin{abstract}
The potential evapotranspiration was estimated using different mass transfer-based models and was compared with the Food and Agriculture Organization Penman-Monteith model. The results showed that the Albrecht model estimates the potential evapotranspiration better than the other models in the most provinces of Iran (23 provinces). The best values of $R^{2}$ were 0.9854 and 0.9826 for the Brockamp-Wenner and Albrecht models in Bushehr (BU) and Tehran provinces, respectively. Finally, a list of the best performance of each model has been presented. The best weather conditions (not only for Iran but also for all countries) to use mass transfer-based equations are 23.624.6 $\mathrm{MJ} \mathrm{m}^{-2}$ day $^{-1}, 12-26{ }^{\circ} \mathrm{C}, 18-30{ }^{\circ} \mathrm{C}, 5-21{ }^{\circ} \mathrm{C}$, and 2.50 $3.25 \mathrm{~m} \mathrm{~s}^{-1}$ (with the exception of Penman) for solar radiation, mean temperature, maximum temperature, minimum temperature, and wind speed, respectively. The results are also useful for selecting the best model when researchers must apply mass transfer (humidity)-based models on the basis of available data. In addition, the designed maps and categories are applicable for considering the role of climatic parameters in architectural evaluations over Iran.
\end{abstract}

Keywords Architecture - Evapotranspiration · FAOPenmanMonteith · Humidity · Iran · Linear regression · Mass transfer . Optimum design $\cdot$ Prevailing wind

Mina Rezaei

mohammadvalipour@gmail.com

1 Department of Architecture, Kermanshah Branch, Islamic Azad University, Kermanshah, Iran

2 Rezvan High School, Education of Region 1, Kermanshah, Iran

3 Young Researchers and Elite Club, Kermanshah Branch, Islamic Azad University, Kermanshah, Iran

\section{Introduction}

The best estimations of actual evapotranspiration are obtained by using a lysimeter or imaging techniques, the costs of which are very high [1-7]. Thus, the Food and Agriculture Organization (FAO) Penman-Monteith model [8] has become one modelling approach to estimate the potential evapotranspiration [9-14]. Although the FAO Penman-Monteith (FPM) model has been applied in various regions of the world [15-24], its application requires many parameters which are often difficult to obtain. To this end, experimental models have been developed for estimation of the potential evapotranspiration using limited data. They include mass transfer, radiation, temperature, and pan evaporation-based models. The mass transfer-based model is one of the most widely used models to estimate potential evapotranspiration. The common mass transfer-based models include Papadakis, Rohwer, Dalton, Ivanov, Meyer, Trabert, and World Meteorological Organization (WMO) [25-35].

Azhar and Perera [36] calibrated the Meyer model as well as nine other (temperature and radiation-based) models under Southeast Australian Conditions successfully. Acheampong [2] considered the Penman, Thornthwaite, and Papadakis models for the estimation of the potential evapotranspiration for Ghana. Under the varying weather and climatic conditions over the country, the modified Penman method was found to be most suitable for estimating the potential evapotranspiration for Ghana. More examination of the performance resulted in the following rank of preciseness as compared with the FPM estimates: Priestley-Taylor, Makkink, Hargreaves, Blaney-Criddle, and Rohwer [37]. The adjusted Dalton model gives the better estimation of the potential evapotranspiration compared with the adjusted Penman-Monteith model for the Kendall subwatershed located in Tucson, Arizona [38]. The top six methods obtained for the average as well as for central Saudi Arabia ratings are ranked in the following order of merit: Jensen-Haise, class A 
pan, Ivanov, adjusted class A pan, Behnke-Maxey, and Stephens-Stewart [39]. Hargreaves [40] calibrated the Hargreaves, Makkink, Turc, Priestley-Taylor, Jensen-Haise, Doorenbos-Pruitt, Abtew, McGuinness-Bordne, Rohwer, and Blaney-Criddle models. It can be concluded that calibration can be used to modify the potential evapotranspiration equations with multi-station data to improve the preciseness of the potential evapotranspiration estimates in Northwest China. Singh and $\mathrm{Xu}$ [51] evaluated the Meyer, Dalton, and Rohwer models for determining free water evaporation at four climatological stations in Northwestern Ontario, Canada. The results of the comparison showed that all equations were in reasonable agreement with observed evaporation. Jakimavicius et al. [41] compared the Dalton, Trabert, Meyer, WMO, Mahringer, Thornthwaite, Schendel, Hargreaves-Samani, Irmak, and Kay-Davies models. The study revealed that the Thornthwaite and Schendel models gave the most precise assessment in estimating the evaporation from the Curonian Lagoon, Baltic. Bormann [34] compared the Dalton, Trabert, Meyer, WMO, and Mahringer models with some of other temperature and radiation-based models to analyse climatic change in Germany. He showed significant difference between performances of all models.

In the previous studies, one or more of the mass transfer-based models have been compared with temperature, radiation, or pan evaporation-based models and, in the most of the cases, other models (temperature, radiation, or pan evaporation-based models) estimated the potential evapotranspiration better than the mass transfer-based models. The previous studies focus on specific (humid, arid, semi-arid, etc.) weather conditions (that they are not suitable for applying the mass transfer-based model) and/or did not consider many methods of mass transfer-based models. Moreover, the results of previous studies are not useable for estimation of the potential evapotranspiration in other regions. Because they were recommended for one or more climatic conditions, there was a climatic condition that contains a wide range of magnitude of each weather parameter (e.g. temperature, relative humidity, wind speed, and solar radiation) and the results of each research (for a region with specific weather variations) are not applicable to other regions without determining specified ranges of each weather parameter even if climatic conditions (e.g. humid, arid, semi-arid, and temperate) are identical for both regions. In addition, the governments cannot schedule for irrigation and agricultural water management when the potential evapotranspiration is estimated for a basin, wetland, watershed, or catchment instead a state or province (different parts of them are located in more than one state or province) and/or the number of weather station used is low (increasing uncertainty). This study aims to estimate the potential evapotranspiration for 31 provinces of Iran (considering various weather conditions and being useful for long-term and macroeconomic policies of governments) using the average data of 181 synoptic stations (decreasing uncertainty) and by 11 mass transfer-based models to determine the best model based on the weather conditions of each province (for which ranges of weather parameters have been determined to use other regions and next researches).

\section{Material and Methods}

In this study, weather information (from 1986 to 2005) has been gathered from 181 synoptic stations of 31 provinces of Iran (without data gaps). Table 1 shows the position of each province and the number of stations.

In each station, the average of weather data in years measured has been considered as the value of that weather parameter in each month (e.g. the value of relative humidity in July for North Khorasan (NK) is an average of 20 data gathered). Finally, the average of data in all stations has been considered as the value of that weather parameter in each month for provinces with more than one station (e.g. the value of relative humidity in July for Khuzestan $(\mathrm{KH})$ is an average of $20 \times 14=280$ data gathered). All of the data mentioned have been used to estimate the potential evapotranspiration using 11 mass transfer-based models and were compared with the FPM model to determine the best model based on the weather conditions of each province (Table 2).

The best model for each province and the best performance of each model were determined using the coefficient of determination

$$
R^{2}=1-\frac{\sum\left(\mathrm{ET}_{\mathrm{FPM}_{i}}-\mathrm{ET}_{\mathrm{m}_{i}}\right)^{2}}{\sum\left(\mathrm{ET}_{\mathrm{FPM}_{i}}-\frac{\sum \mathrm{ET}_{\mathrm{FPM}_{i}}}{12}\right)^{2}}
$$

where $i$ indicates the month, $\mathrm{ET}_{\mathrm{FPM}}$ indicates the potential evapotranspiration calculated for FPM model, and $\mathrm{ET}_{\mathrm{m}}$ indicates the potential evapotranspiration calculated for mass transfer-based models.

Finally, a map of the annual average of solar radiation, mean temperature, maximum temperature, minimum temperature, relative humidity, and wind speed was provided and the best performance of each model based on these values was determined. Furthermore, the map of the best model for each province and the map of the error calculated for each province have been presented.

\section{Results and Discussion}

\section{Estimating the Potential Evapotranspiration for 31 Provinces of Iran}

Table 3 shows the errors for each model and province.

According to the $R^{2}$ values, each model estimates the potential evapotranspiration for only one or few 
Table 1 Position of all provinces and synoptic stations

\begin{tabular}{|c|c|c|c|}
\hline Province & Latitude $(\mathrm{N})$ & Longitude (E) & Number of station \\
\hline Alborz (AL) & $35^{\circ} 55^{\prime}$ & $50^{\circ} 54^{\prime}$ & 1 \\
\hline Ardabil (AR) & $38^{\circ} 15^{\prime}$ & $48^{\circ} 17^{\prime}$ & 4 \\
\hline Bushehr (BU) & $28^{\circ} 59^{\prime}$ & $50^{\circ} 50^{\prime}$ & 5 \\
\hline Chaharmahal and Bakhtiari (CB) & $32^{\circ} 17^{\prime}$ & $50^{\circ} 51^{\prime}$ & 4 \\
\hline East Azerbaijan (EA) & $38^{\circ} 05^{\prime}$ & $46^{\circ} 17^{\prime}$ & 10 \\
\hline Esfahan (ES) & $32^{\circ} 37^{\prime}$ & $51^{\circ} 40^{\prime}$ & 12 \\
\hline Fars (FA) & $29^{\circ} 32^{\prime}$ & $52^{\circ} 36^{\prime}$ & 9 \\
\hline Ghazvin $(\mathrm{GH})$ & $36^{\circ} 15^{\prime}$ & $50^{\circ} 03^{\prime}$ & 2 \\
\hline Gilan (GI) & $37^{\circ} 15^{\prime}$ & $49^{\circ} 36^{\prime}$ & 4 \\
\hline Gorgan (GO) & $36^{\circ} 51^{\prime}$ & $54^{\circ} 16^{\prime}$ & 3 \\
\hline Hamadan (HA) & $34^{\circ} 52^{\prime}$ & $48^{\circ} 32^{\prime}$ & 4 \\
\hline Hormozgan (HO) & $27^{\circ} 13^{\prime}$ & $56^{\circ} 22^{\prime}$ & 9 \\
\hline Ilam (IL) & $33^{\circ} 38^{\prime}$ & $46^{\circ} 26^{\prime}$ & 3 \\
\hline Kohgiluyeh and Boyer-Ahmad (KB) & $30^{\circ} 50^{\prime}$ & $51^{\circ} 41^{\prime}$ & 1 \\
\hline Kerman (KE) & $30^{\circ} 15^{\prime}$ & $56^{\circ} 58^{\prime}$ & 8 \\
\hline Khuzestan (KH) & $31^{\circ} 20^{\prime}$ & $48^{\circ} 40^{\prime}$ & 14 \\
\hline Kurdistan (KO) & $35^{\circ} 20^{\prime}$ & $47^{\circ} 00^{\prime}$ & 7 \\
\hline Kermanshah (KS) & $34^{\circ} 21^{\prime}$ & $47^{\circ} 09^{\prime}$ & 6 \\
\hline Lorestan (LO) & $33^{\circ} 26^{\prime}$ & $48^{\circ} 17^{\prime}$ & 9 \\
\hline Markazi (MA) & $34^{\circ} 06^{\prime}$ & $49^{\circ} 46^{\prime}$ & 4 \\
\hline Mazandaran (MZ) & $36^{\circ} 33^{\prime}$ & $53^{\circ} 00^{\prime}$ & 7 \\
\hline North Khorasan (NK) & $37^{\circ} 28^{\prime}$ & $57^{\circ} 16^{\prime}$ & 1 \\
\hline Qom (QO) & $34^{\circ} 42^{\prime}$ & $50^{\circ} 51^{\prime}$ & 1 \\
\hline Razavi Khorasan (RK) & $36^{\circ} 16^{\prime}$ & $59^{\circ} 38^{\prime}$ & 12 \\
\hline Sistan and Baluchestan (SB) & $29^{\circ} 28^{\prime}$ & $60^{\circ} 05^{\prime}$ & 8 \\
\hline Semnan (SE) & $35^{\circ} 35^{\prime}$ & $53^{\circ} 33^{\prime}$ & 4 \\
\hline South Khorasan (SK) & $32^{\circ} 52^{\prime}$ & $59^{\circ} 12^{\prime}$ & 3 \\
\hline Tehran (TE) & $35^{\circ} 41^{\prime}$ & $51^{\circ} 19^{\prime}$ & 8 \\
\hline West Azerbaijan (WA) & $37^{\circ} 32^{\prime}$ & $45^{\circ} 05^{\prime}$ & 8 \\
\hline Yazd (YA) & $31^{\circ} 54^{\prime}$ & $54^{\circ} 17^{\prime}$ & 6 \\
\hline Zanjan (ZA) & $36^{\circ} 41^{\prime}$ & $48^{\circ} 29^{\prime}$ & 4 \\
\hline
\end{tabular}

provinces with very high accuracy. In the other words, preciseness of estimation by mass transfer-based models is very sensitive to variations of the parameters used in each model (Table 2).

Table 2 Model used and parameters applied in each model

\begin{tabular}{|c|c|c|c|}
\hline Model & Reference(s) & Formula & Parameters \\
\hline FAO Penman-Monteith & Allen et al. [8] & $\mathrm{ET}_{\mathrm{o}}=0.408\left(R_{\mathrm{n}}-G\right) \frac{+\gamma_{\frac{900}{T+273} u}\left(e_{\mathrm{s}}-e_{\mathrm{a}}\right)}{\Delta+\gamma(1+0.34 u)}$ & $H, \varphi, T, T_{\min }, T_{\max }, \mathrm{RH}, u, n$ \\
\hline Albrecht & Albrecht [3] & $\mathrm{ET}_{\mathrm{o}}=(1.005+2.97 u)\left(e_{\mathrm{s}}-e_{\mathrm{a}}\right)$ & $T, T_{\min }, T_{\max }, \mathrm{RH}, u$ \\
\hline Brockamp-Wenner & Brockamp and Wenner [25] & $\mathrm{ET}_{\mathrm{o}}=5.43 u^{0.456}\left(e_{\mathrm{s}}-e_{\mathrm{a}}\right)$ & $T, T_{\min }, T_{\max }, \mathrm{RH}, u$ \\
\hline Dalton & Dalton [26] & $\mathrm{ET}_{\mathrm{o}}=(3.648+0.7223 u)\left(e_{\mathrm{s}}-e_{\mathrm{a}}\right)$ & $T, T_{\min }, T_{\max }, \mathrm{RH}, u$ \\
\hline Ivanov & Romanenko [31] & $\mathrm{ET}_{\mathrm{o}}=0.00006(25+T)^{2}(100-\mathrm{RH})$ & $T, \mathrm{RH}$ \\
\hline Mahringer & Mahringer [27] & $\mathrm{ET}_{\mathrm{o}}=2.8597 u^{0.5}\left(e_{\mathrm{s}}-e_{\mathrm{a}}\right)$ & $T, T_{\min }, T_{\max }, \mathrm{RH}, u$ \\
\hline Meyer & Meyer [28] & $\mathrm{ET}_{\mathrm{o}}=(3.75+0.5026 u)\left(e_{\mathrm{s}}-e_{\mathrm{a}}\right)$ & $T, T_{\min }, T_{\max }, \mathrm{RH}, u$ \\
\hline Papadakis & Papadakis [33] & $\mathrm{ET}_{\mathrm{o}}=2.5\left(e_{\mathrm{ma}}-e_{\mathrm{a}}\right)$ & $T_{\min }, T_{\max }, \mathrm{RH}$ \\
\hline Penman & Penman [29] & $\mathrm{ET}_{\mathrm{o}}=(2.625+0.000479 / u)\left(e_{\mathrm{s}}-e_{\mathrm{a}}\right)$ & $T, T_{\min }, T_{\max }, \mathrm{RH}, u$ \\
\hline Rohwer & Rohwer [30] & $\mathrm{ET}_{\mathrm{o}}=(3.3+0.891 u)\left(e_{\mathrm{s}}-e_{\mathrm{a}}\right)$ & $T, T_{\min }, T_{\max }, \mathrm{RH}, u$ \\
\hline Trabert & Trabert [32] & $\mathrm{ET}_{\mathrm{o}}=3.075 u^{0.5}\left(e_{\mathrm{s}}-e_{\mathrm{a}}\right)$ & $T, T_{\min }, T_{\max }, \mathrm{RH}, u$ \\
\hline WMO & $\mathrm{WMO}[35]$ & $\mathrm{ET}_{\mathrm{o}}=(1.298+0.934 u)\left(e_{\mathrm{s}}-e_{\mathrm{a}}\right)$ & $T, T_{\min }, T_{\max }, \mathrm{RH}, u$ \\
\hline
\end{tabular}

$\mathrm{ET}_{\mathrm{o}}$ is the reference crop evapotranspiration $\left(\mathrm{mm} \mathrm{day}^{-1}\right) \cdot R_{\mathrm{n}}$ is the net radiation $\left(\mathrm{MJ} \mathrm{m}^{-2}\right.$ day $\left.^{-1}\right)$. $G$ is the soil heat flux $\left(\mathrm{MJ} \mathrm{m}^{-2}\right.$ day $\left.^{-1}\right) \cdot \gamma$ is the psychrometric constant $\left(\mathrm{kPa} /{ }^{\circ} \mathrm{C}\right) . e_{\mathrm{s}}$ is the saturation vapour pressure $(\mathrm{kPa}) . e_{\mathrm{a}}$ is the actual vapour pressure $(\mathrm{kPa}) . \Delta$ is the slope of the saturation vapour pressure-temperature curve $\left(\mathrm{kPa} /{ }^{\circ} \mathrm{C}\right) . T$ is the average daily air temperature $\left({ }^{\circ} \mathrm{C}\right) . u$ is the mean daily wind speed at $2 \mathrm{~m}\left(\mathrm{~m} \mathrm{~s}^{-1}\right) . H$ is the elevation $(\mathrm{m}) . \varphi$ is the latitude (rad). $T_{\min }$ is the minimum air temperature $\left({ }^{\circ} \mathrm{C}\right) . T_{\max }$ is the maximum air temperature $\left({ }^{\circ} \mathrm{C}\right) . \mathrm{RH}$ is the average relative humidity $(\%) . n$ is the actual duration of sunshine (h). $R_{\mathrm{s}}$ is the solar radiation $\left(\mathrm{MJ} \mathrm{m}^{-2}\right.$ day $\left.{ }^{-1}\right) \cdot e_{\mathrm{ma}}$ is the saturation vapour pressure at the monthly mean daily maximum temperature $(\mathrm{kPa})$ 
Table 3 Error of the model calculated for each province

\begin{tabular}{|c|c|c|c|c|c|c|c|c|c|c|c|}
\hline & Al. & BW & Da. & Iv. & Ma. & Me. & $\mathrm{Pa}$. & Pe. & Ro. & Tr. & WMO \\
\hline $\mathrm{CB}$ & 0.9671 & 0.9251 & 0.8806 & 0.8586 & 0.9319 & 0.8696 & 0.8192 & 0.839 & 0.8911 & 0.9319 & 0.9295 \\
\hline EA & 0.9397 & 0.9567 & 0.9555 & 0.9601 & 0.9557 & 0.9571 & 0.9596 & 0.9575 & 0.9537 & 0.9557 & 0.9468 \\
\hline WA & 0.962 & 0.94 & 0.9221 & 0.9167 & 0.9431 & 0.9168 & 0.8926 & 0.9012 & 0.9271 & 0.9431 & 0.9443 \\
\hline AR & 0.9487 & 0.9601 & 0.9599 & 0.9568 & 0.9596 & 0.9603 & 0.9415 & 0.956 & 0.9592 & 0.9596 & 0.9547 \\
\hline $\mathrm{ES}$ & 0.978 & 0.9424 & 0.9218 & 0.8907 & 0.9477 & 0.9096 & 0.8464 & 0.8663 & 0.9321 & 0.9477 & 0.9604 \\
\hline IL & 0.943 & 0.9345 & 0.9295 & 0.9271 & 0.9358 & 0.9267 & 0.9222 & 0.9166 & 0.9318 & 0.9358 & 0.9382 \\
\hline $\mathrm{BU}$ & 0.961 & 0.9854 & 0.9837 & 0.9684 & 0.9852 & 0.9802 & 0.8932 & 0.95 & 0.9849 & 0.9852 & 0.9783 \\
\hline $\mathrm{TE}$ & 0.9826 & 0.9506 & 0.9403 & 0.9075 & 0.9551 & 0.9297 & 0.8969 & 0.8879 & 0.9488 & 0.9551 & 0.9702 \\
\hline $\mathrm{AL}$ & 0.9687 & 0.9519 & 0.942 & 0.9164 & 0.9545 & 0.9357 & 0.9165 & 0.9115 & 0.9471 & 0.9545 & 0.9606 \\
\hline SK & 0.9564 & 0.9716 & 0.9694 & 0.9453 & 0.9711 & 0.9689 & 0.9258 & 0.9576 & 0.9691 & 0.9711 & 0.9643 \\
\hline RK & 0.9585 & 0.9597 & 0.9566 & 0.9473 & 0.9601 & 0.9552 & 0.941 & 0.9486 & 0.9576 & 0.9601 & 0.9592 \\
\hline NK & 0.9479 & 0.9537 & 0.9491 & 0.9309 & 0.9541 & 0.9468 & 0.9289 & 0.9321 & 0.9505 & 0.9541 & 0.9512 \\
\hline $\mathrm{KH}$ & 0.9683 & 0.9673 & 0.9634 & 0.9497 & 0.9684 & 0.9597 & 0.919 & 0.9399 & 0.9658 & 0.9684 & 0.9695 \\
\hline $\mathrm{ZA}$ & 0.945 & 0.9333 & 0.9251 & 0.9163 & 0.935 & 0.9215 & 0.9066 & 0.9097 & 0.9282 & 0.935 & 0.9376 \\
\hline $\mathrm{SE}$ & 0.9553 & 0.9447 & 0.9323 & 0.9337 & 0.9466 & 0.9285 & 0.9219 & 0.9161 & 0.9357 & 0.9466 & 0.9463 \\
\hline $\mathrm{SB}$ & 0.9766 & 0.9692 & 0.9655 & 0.9228 & 0.9714 & 0.9589 & 0.8846 & 0.925 & 0.97 & 0.9714 & 0.9775 \\
\hline FA & 0.9681 & 0.9439 & 0.9334 & 0.9138 & 0.9471 & 0.9262 & 0.8944 & 0.9001 & 0.9394 & 0.9471 & 0.9562 \\
\hline QO & 0.9595 & 0.9498 & 0.9384 & 0.914 & 0.9519 & 0.9319 & 0.8929 & 0.9055 & 0.9433 & 0.9519 & 0.9549 \\
\hline $\mathrm{GH}$ & 0.9558 & 0.9437 & 0.936 & 0.9253 & 0.9454 & 0.9321 & 0.9177 & 0.9183 & 0.9393 & 0.9454 & 0.9487 \\
\hline $\mathrm{KO}$ & 0.9388 & 0.9209 & 0.9123 & 0.9094 & 0.9231 & 0.9081 & 0.8968 & 0.8946 & 0.9161 & 0.9231 & 0.928 \\
\hline $\mathrm{KE}$ & 0.9779 & 0.9677 & 0.9636 & 0.9353 & 0.9696 & 0.9582 & 0.897 & 0.9309 & 0.9675 & 0.9696 & 0.9752 \\
\hline $\mathrm{KS}$ & 0.9438 & 0.9287 & 0.9237 & 0.9136 & 0.9304 & 0.9202 & 0.9175 & 0.908 & 0.9268 & 0.9304 & 0.936 \\
\hline $\mathrm{KB}$ & 0.9178 & 0.9059 & 0.8895 & 0.8758 & 0.9082 & 0.8849 & 0.8731 & 0.8707 & 0.8937 & 0.9082 & 0.907 \\
\hline $\mathrm{GO}$ & 0.9555 & 0.9452 & 0.9229 & 0.9066 & 0.9475 & 0.9175 & 0.9007 & 0.9009 & 0.9277 & 0.9475 & 0.9432 \\
\hline GI & 0.971 & 0.9683 & 0.9633 & 0.9689 & 0.9689 & 0.9622 & 0.9251 & 0.9592 & 0.9643 & 0.9689 & 0.9679 \\
\hline LO & 0.9234 & 0.9059 & 0.8959 & 0.893 & 0.9081 & 0.8925 & 0.8869 & 0.8825 & 0.8991 & 0.9081 & 0.9106 \\
\hline $\mathrm{MZ}$ & 0.964 & 0.9344 & 0.9178 & 0.9191 & 0.9383 & 0.9101 & 0.8617 & 0.8853 & 0.9245 & 0.9383 & 0.9459 \\
\hline MA & 0.9548 & 0.9236 & 0.9003 & 0.8867 & 0.9279 & 0.8924 & 0.8632 & 0.8689 & 0.9074 & 0.9279 & 0.9317 \\
\hline $\mathrm{HO}$ & 0.9742 & 0.9558 & 0.947 & 0.8083 & 0.959 & 0.9381 & 0.8165 & 0.8954 & 0.9535 & 0.959 & 0.9676 \\
\hline HA & 0.9687 & 0.9292 & 0.9003 & 0.8767 & 0.9351 & 0.8893 & 0.834 & 0.8566 & 0.9101 & 0.9351 & 0.9425 \\
\hline YA & 0.9639 & 0.9524 & 0.9468 & 0.9289 & 0.9542 & 0.942 & 0.912 & 0.9219 & 0.9505 & 0.9542 & 0.9594 \\
\hline
\end{tabular}

The values in italics show the best value of each method, and the values in bold show the best value of each province

Al. Albrecht, $B W$ Brockamp-Wenner, Da. Dalton, $I v$. Ivanov, Ma. Mahringer, Me. Meyer, Pa. Papadakis, Pe. Penman, Ro. Rohwer, Tr. Trabert

\section{Comparison of the Best Models for Each Province}

Figure 1 compares the potential evapotranspiration using the FPM model with values estimated using the best method (based on Table 3) for each province.

According to Fig. 1, the Brockamp-Wenner model for Bushehr (BU) $\left(R^{2}=0.9854\right)$ yielded the best the potential evapotranspiration as compared to that from the FPM model. However, the Albrecht model has been introduced as the best model in the most of the provinces (23 provinces). In general, mass transferbased models are more suitable $\left(R^{2}\right.$ more than 0.97$)$ for $\mathrm{BU}$, Hormozgan (HO) (near the Persian Gulf), South Khorasan (SK), Kerman (KE), and Sistan and Baluchestan (SB) (southeast of Iran) and for Tehran (TE), Gilan (GI), and Esfahan (ES) (south of Iran). However, according to Table 3, variations of the errors (the worst and best $R^{2}$ ) for different models are too high in all provinces, e.g. Chaharmahal and Bakhtiari (CB) (0.839 and 0.9671 for the Penman and Albrecht models, respectively), BU (0.8932 and 0.9854 for the Papadakis and Albrecht models, respectively), SB (0.8846 and 0.9775 for the Papadakis and WMO models, respectively), and $\mathrm{HO}(0.8083$ and 0.9742 for the Ivanov and Albrecht models, respectively). These values indicate very different performances of the mass transfer-based models for a specific weather condition in each province. For instance, the Ivanov model estimates the potential evapotranspiration with the least $R^{2}$ for $\mathrm{HO}$ and the greatest $R^{2}$ for East Azerbaijan (EA) than the other models. However, according to Table 2, the Ivanov model is a function of mean temperature and relative 

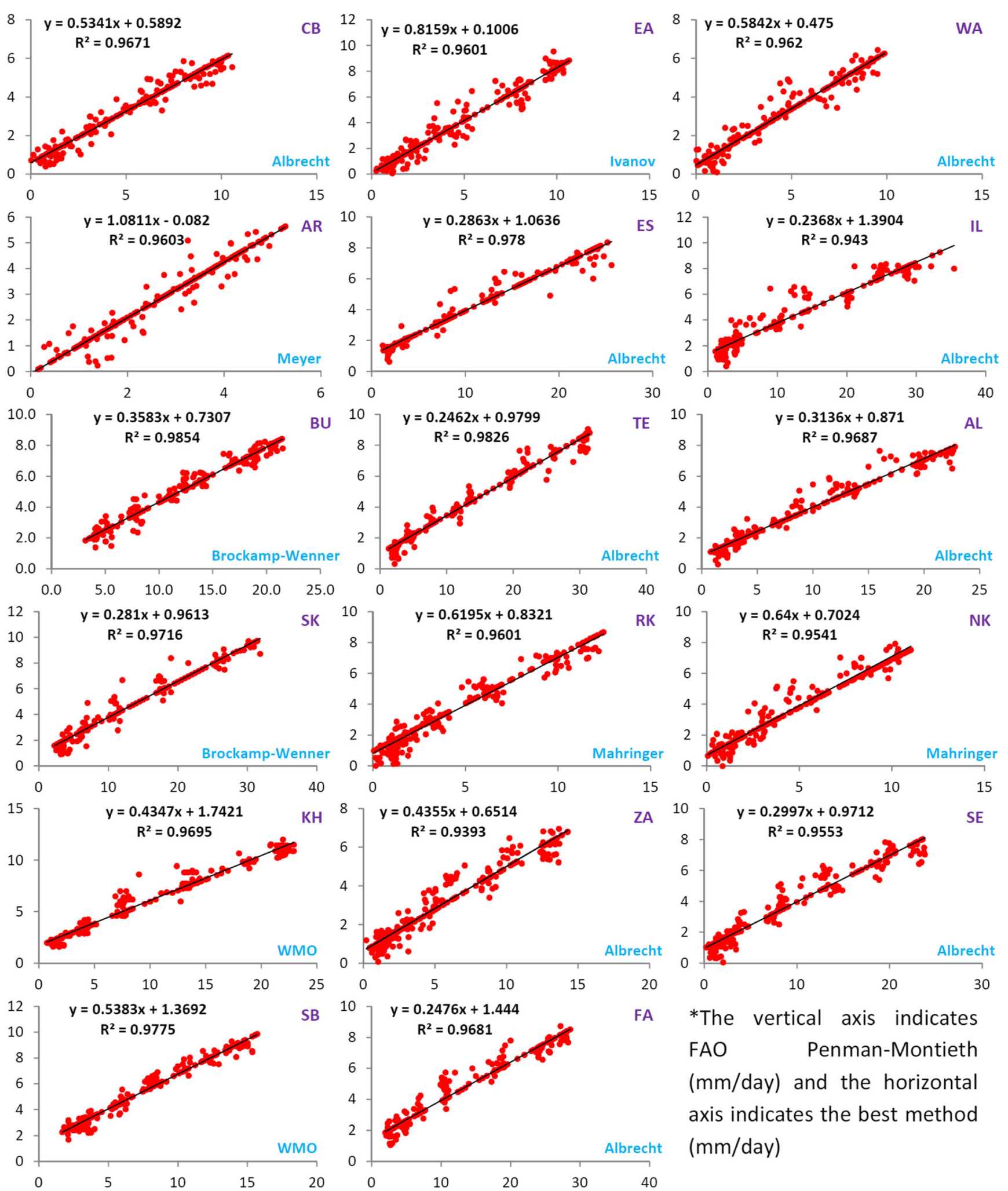

*The vertical axis indicates

FAO Penman-Montieth

(mm/day) and the horizontal

axis indicates the best method

$(\mathrm{mm} /$ day)

Fig. 1 Comparison of the evapotranspiration $\left(\mathrm{mm} \mathrm{day}^{-1}\right)$ calculated using the FAO Penman-Monteith (FPM) model with the best model for each province. The vertical axis indicates the FAO Penman-Monteith $\left(\mathrm{mm} \mathrm{day}^{-1}\right)$ model, and the horizontal axis indicates the best method ( $\mathrm{mm}$ day ${ }^{-1}$ )

humidity, the Papadakis model is a function of minimum and maximum temperatures and relative humidity, and the other models are a function of mean, minimum, and maximum temperatures; relative humidity; and wind speed. In addition, the only difference among the Albrecht, Dalton, Meyer, Rohwer, and WMO models is coefficients used in each model 

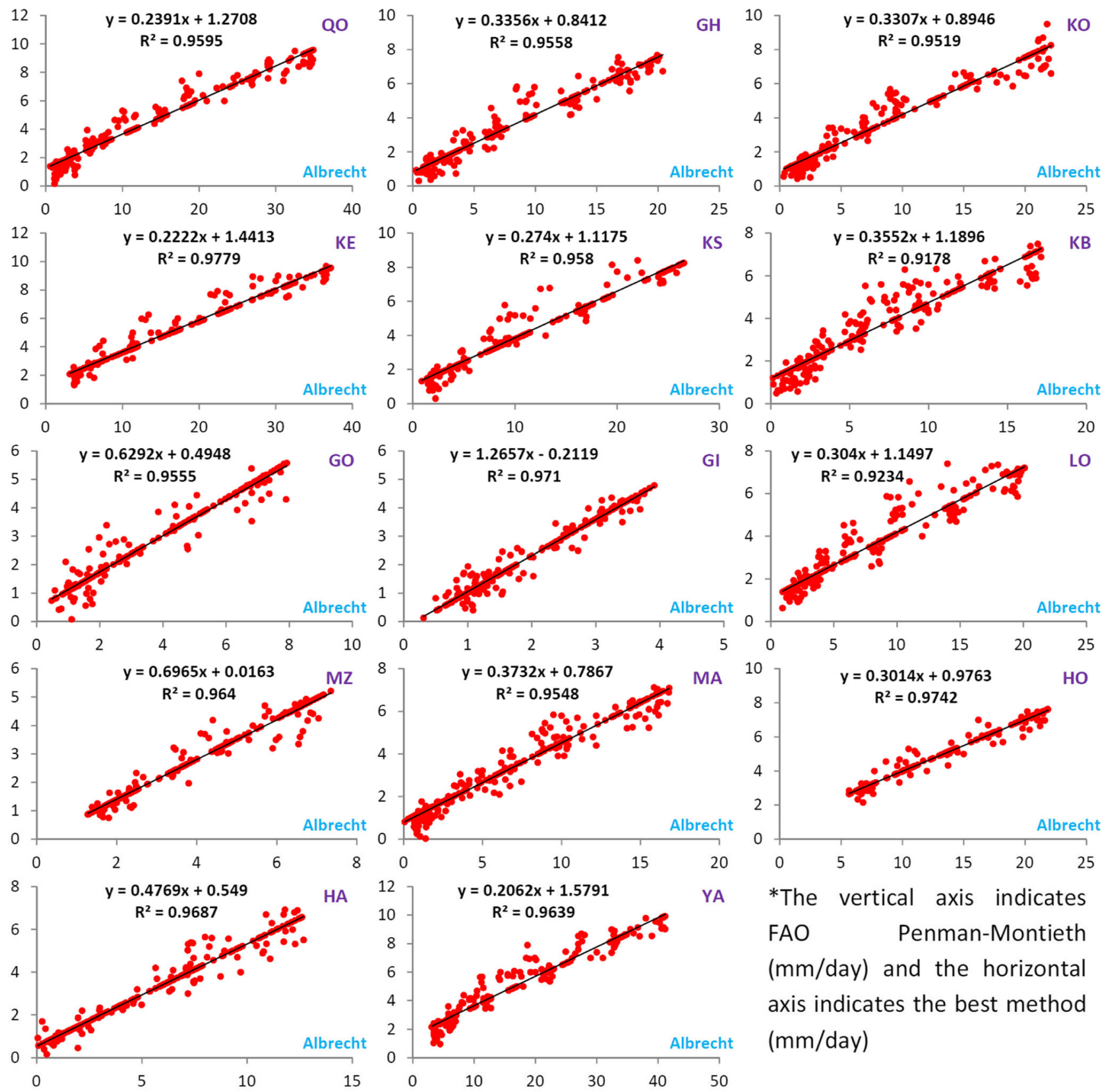

*The vertical axis indicates

FAO

Penman-Montieth

(mm/day) and the horizontal

axis indicates the best method

(mm/day)

Fig. 1 (continued)

(Table 2) and the only difference among the Brockamp-Wenner, Mahringer, and Trabert models is also coefficients used in each model (Table 2). Thus, we must use them according to their best weather conditions (with the most accuracy).

\section{Distinguishing Various Regions Based on Weather Conditions}

The maps of the annual average of the weather parameters have been provided to detect the best conditions (range of weather parameters) that each model estimates the potential evapotranspiration with maximum preciseness (Figs. 2 and 3).

Figure 2 shows the annual average of solar radiation and mean, maximum, and minimum temperatures in all 31 provinces of Iran, and Fig. 3 shows the annual average of relative humidity and wind speed in all 31 provinces of Iran. As shown, the value of solar radiation is more than $25.0 \mathrm{MJ} \mathrm{m}^{-2}$ day $^{-1}$ for the south of Iran, it is from 24.0 to $25.0 \mathrm{MJ} \mathrm{m}^{-2}$ day $^{-1}$ for the centre of Iran, and it ranges less than $24.0 \mathrm{MJ} \mathrm{m}^{-2}$ day $^{-1}$ for the north of Iran. The mean temperature is less than $14{ }^{\circ} \mathrm{C}$ for the north-west of Iran, it is more 


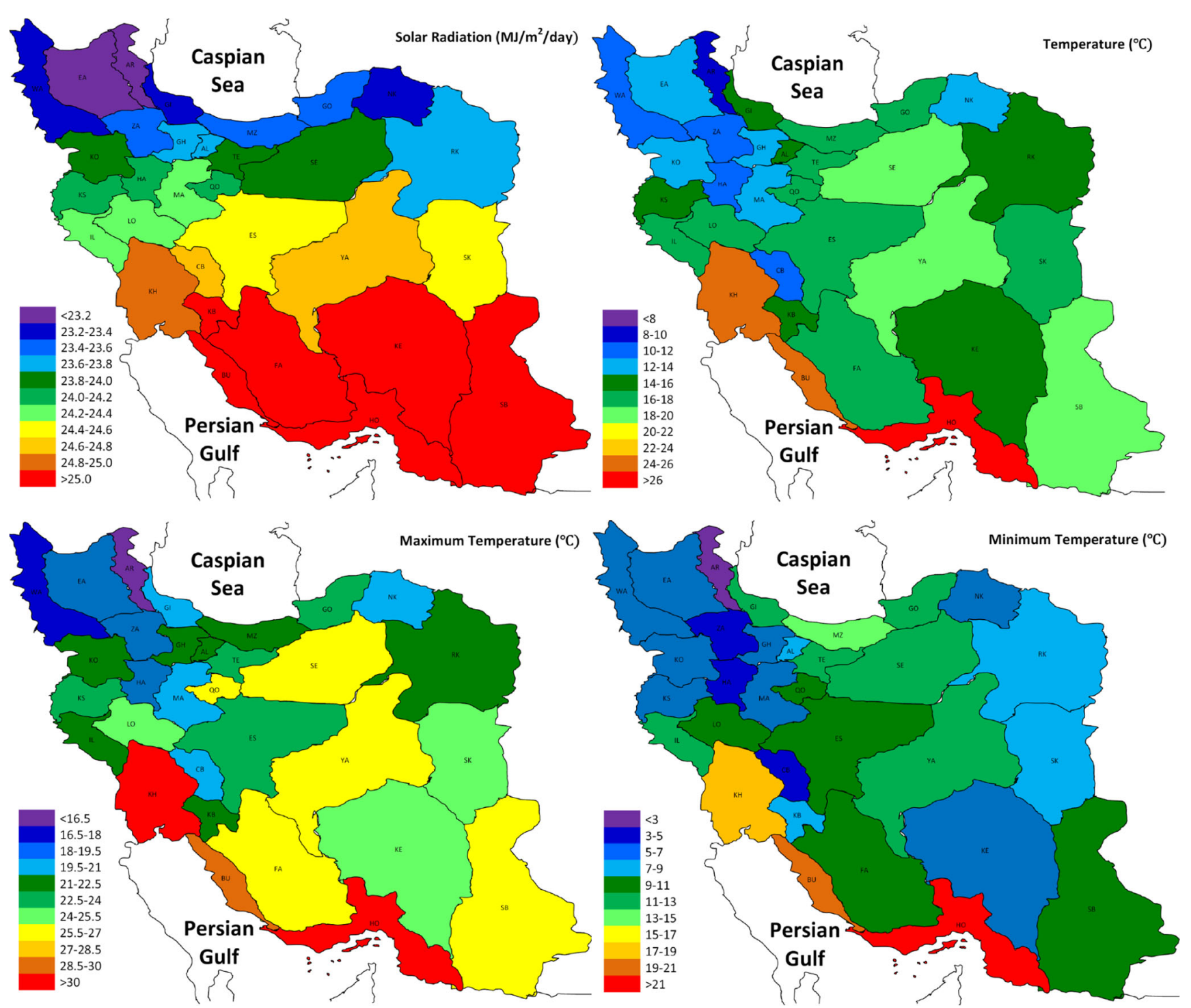

Fig. 2 Average annual variations of solar radiation, mean temperature, maximum temperature, and minimum temperature in Iran
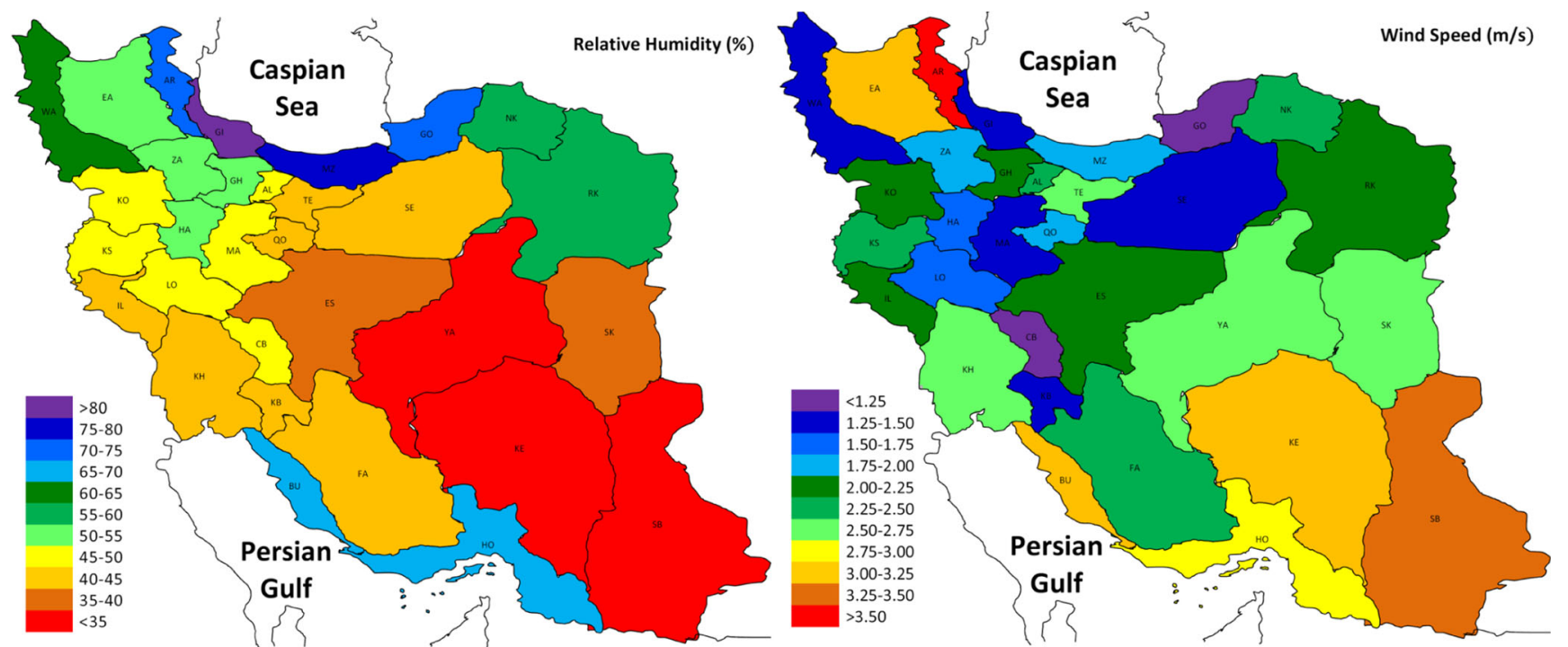

Fig. 3 Average annual variations of relative humidity and wind speed in Iran 
Table 4 The best range to use the models based on the results of the current study

\begin{tabular}{lllllll}
\hline Model & $T$ & $T_{\max }$ & $T_{\min }$ & $\mathrm{RH}$ & $u$ & $R^{2}$ \\
\hline Albrecht & $16-18$ & $22.5-24.0$ & $11-13$ & $40-45$ & $2.50-2.75$ & 0.9826 \\
Brockamp-Wenner & $24-26$ & $28.5-30$ & $19-21$ & $65-70$ & $3.00-3.25$ & 0.9854 \\
Dalton & $16-18$ & $24.0-25.5$ & $7-9$ & $35-40$ & $2.50-2.75$ & 0.9694 \\
Ivanov & $14-16$ & - & - & $>80$ & - & 0.9689 \\
Mahringer & $24-26$ & $28.5-30$ & $19-21$ & $65-70$ & $3.00-3.25$ & 0.9852 \\
Meyer & $24-26$ & $28.5-30$ & $19-21$ & $65-70$ & $3.00-3.25$ & 0.9802 \\
Papadakis & $12-14$ & $18.0-19.5$ & $5-7$ & $50-55$ & $3.00-3.25$ & 0.9596 \\
Penman & $14-16$ & $19.5-21.0$ & $11-13$ & $>80$ & $1.25-1.50$ & 0.9592 \\
Rohwer & $18-20$ & $25.5-27.0$ & $9-11$ & $<35$ & $3.25-3.50$ & 0.97 \\
Trabert & $24-26$ & $28.5-30$ & $19-21$ & $65-70$ & $3.00-3.25$ & 0.9852 \\
WMO & $24-26$ & $28.5-30$ & $19-21$ & $65-70$ & $3.00-3.25$ & 0.9783 \\
\hline
\end{tabular}

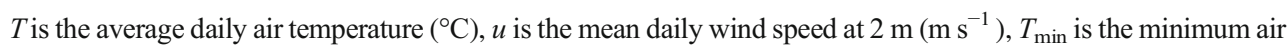
temperature $\left({ }^{\circ} \mathrm{C}\right), T_{\max }$ is the maximum air temperature $\left({ }^{\circ} \mathrm{C}\right)$, and $\mathrm{RH}$ is the average relative humidity $(\%)$ than $24{ }^{\circ} \mathrm{C}$ near the Persian Gulf, and it is from 14 to $24^{\circ} \mathrm{C}$ for the other regions (with the exception of $\mathrm{NK}$ and $\mathrm{CB}$ ). The maximum temperature is more than $28.5^{\circ} \mathrm{C}$ near the Persian Gulf, it is from 25.5 to $27.0^{\circ} \mathrm{C}$ for desert provinces, it is less than $19.5^{\circ} \mathrm{C}$ for the north-west of Iran, and it is from 19.5 to $25.5^{\circ} \mathrm{C}$ for the other regions. The minimum temperature is more than $17^{\circ} \mathrm{C}$ near the Persian Gulf, it is less than $7^{\circ} \mathrm{C}$ for the north-west of Iran, it is from 11 to 15 near the Caspian Sea, and it is from 7 to $13{ }^{\circ} \mathrm{C}$ for the other regions (with the exception of $\mathrm{CB}, \mathrm{NK}$, and $\mathrm{KE}$ ). The relative humidity is from 65 to $70 \%$ near the Persian Gulf (with the exception of $\mathrm{KH}$ ), it is from 50 to $65 \%$ in the north-west and north-east of Iran (with the exception of Ardabil (AR)), it is more than $70 \%$ near the Caspian Sea, and it is less than $45 \%$ for the other regions. The wind speed is from 2.50 to $3.50 \mathrm{~m} \mathrm{~s}^{-1}$ for the south-east of Iran and near the Persian Gulf, and it is from 1.25 to $2.75 \mathrm{~m} \mathrm{~s}^{-1}$ for the other regions (with the exception of EA, AR, Gorgan (GO), and $\mathrm{CB}$ ). The wind speed plays an important role in architectural studies to design buildings and structures with respect to the prevailing wind. For instance, in Qazvin, prevailing wind is a south-eastern wind called Raz or Shareh [42, 43]. This wind comes from desert areas of central Iran and is very warm and dry; hence, it is reasonable that a reduction of the wind speed (WS) due to desertification approaches [44] leads to decreasing impacts of the mentioned climate and consequently reducing the $\mathrm{ET}_{\mathrm{o}}$. Therefore, the WS may be introduced as the most influencing factor on variations of the $\mathrm{ET}_{\mathrm{o}}$ in Qazvin.

The mass transfer-based models estimated the potential evapotranspiration in the south (near the Persian Gulf) and south-east (annual relative humidity $65-70$ and $<35 \%$, respectively) of Iran better than in the other provinces (Fig. 1). Therefore, the provinces of Iran are divided into five categories (at least): (I) the provinces near the Persian Gulf (KH, BU, and HO), (II) the provinces near the Caspian Sea (GI,
Mazandaran (MZ), and GO), (III) the provinces of the northeast of Iran (West Azerbaijan (WA), EA, AR, and Zanjan (ZA)), (IV) CB (due to the different weather conditions than the near provinces), and (V) the other provinces. These categories are useful for future studies over Iran because these four parameters (light, temperature, wind, and humidity) can be employed to the optimum design in architectural investigations.

\section{Determining a Range of Weather Parameters for the Best Models}

The maps of the annual average of weather parameters (Figs. 2 and 3) are useful not only for the mentioned categories but also for determining the range of each parameter for which the best preciseness of the mass transfer-based models is obtained (Table 4).

According to Table 4, the best performance of the Brockamp-Wenner, Mahringer, Meyer, Trabert, and WMO models is in similar weather conditions $\left(T=24-26{ }^{\circ} \mathrm{C}\right.$, $T_{\max }=28.5-30.0^{\circ} \mathrm{C}, T_{\min }=19-21^{\circ} \mathrm{C}, \mathrm{RH}=65-70 \%$, and $u=3.00-3.25 \mathrm{~m} \mathrm{~s}^{-1}$ ). However, their preciseness is different (e.g. 0.9783 and 0.9854 for the WMO and Brockamp-Wenner models, respectively). This underlines the important role of selection of the best model for specified weather conditions. Furthermore, we can see different ranges in the Albrecht, Dalton, Ivanov, Penman, Rohwer, and Papadakis models (Table 4). Therefore, we can use the mass transfer-based models for the other regions (in other countries) based on Table 4 with respect to their errors. The best weather conditions to use mass transfer-based equations are 23.624.6 $\mathrm{MJ} \mathrm{m}^{-2}$ day $^{-1}, 12-26{ }^{\circ} \mathrm{C}, 18-30{ }^{\circ} \mathrm{C}, 5-21{ }^{\circ} \mathrm{C}$, and 2.50-3.25 $\mathrm{m} \mathrm{s}^{-1}$ (with the exception of the Penman model) for solar radiation, mean temperature, maximum temperature, minimum temperature, and wind speed, respectively. The 
Fig. 4 The best model for each province and their error
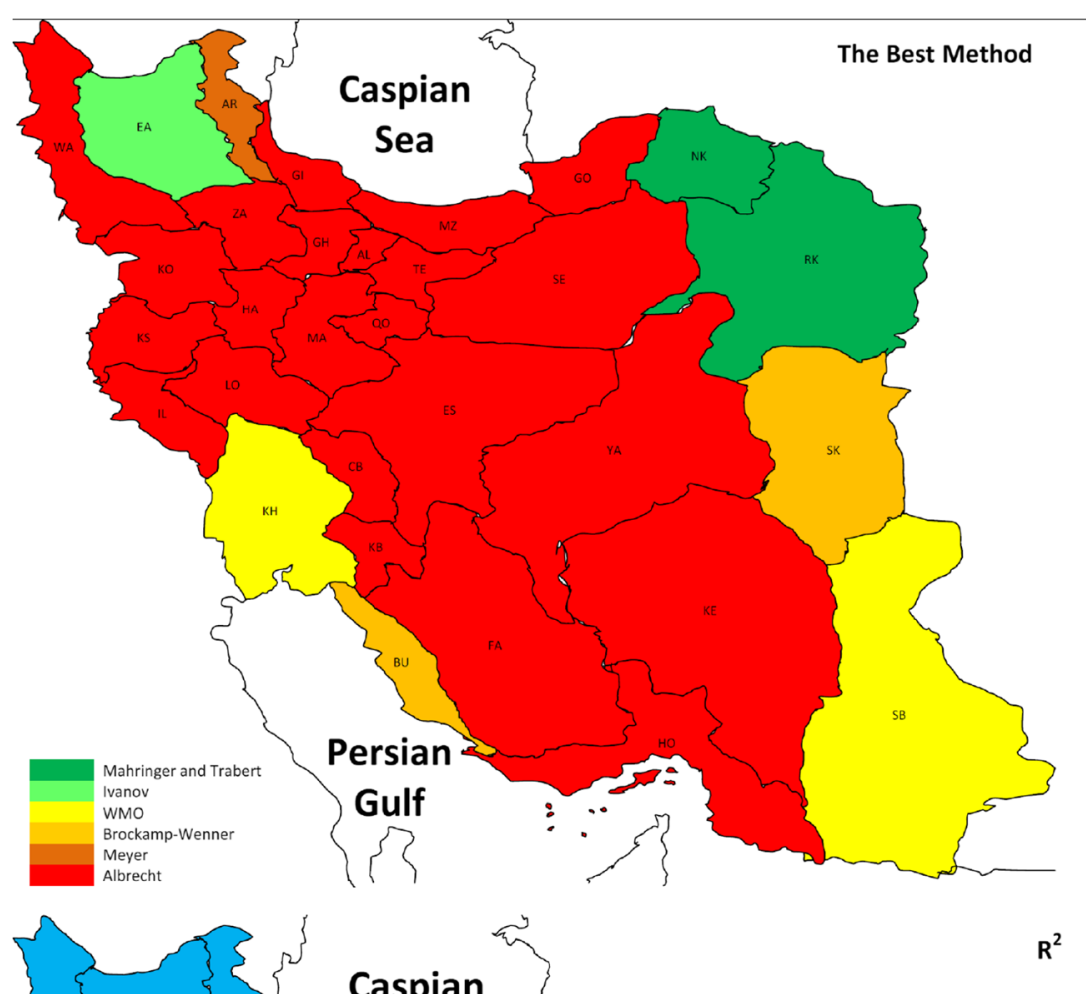

$\mathbf{R}^{2}$ results are also useful for selecting the best model when researchers must apply temperature-based models on the basis of available data.

\section{Comparison of the Best Models with Their Errors for Each Province}

Figure 4 is plotted to detect the best model for each province versus its error (after calibration).
First, although the Albrecht model is the most useful model for provinces of Iran (23 provinces), it is not suitable for two of the categories (near the Persian Gulf and the north-east of Iran) and the east of Iran (NK, RK, SK, and SB). This confirms that the categories are reliable and these two categories need more attention due to specific weather conditions. Moreover, the preciseness of the Albrecht model is less than 0.98 in 18 provinces of Iran. It reveals that the Albrecht model is a general model for estimating the potential evapotranspiration (high application and fair preciseness). Thus, we need 
other temperature-, radiation-, and pan evaporation-based models to estimate the potential evapotranspiration in these 18 provinces. For instance, the values of solar radiation are more than $25.0 \mathrm{MJ} \mathrm{m}^{-2}$ day $^{-1}$ for FA and $\mathrm{KB}$; hence, the radiation-based models may be useful for these provinces [45-55]. It reveals that only if we use the mass transferbased models for suitable (based on Table 4) and specific (based on Figs. 2 and 3) weather conditions, the highest preciseness of estimation will be obtained.

\section{Conclusion}

In this study, 11 mass transfer-based models were used to estimate the potential evapotranspiration in 31 provinces of Iran.

The preciseness of estimation by mass transfer-based models is very sensitive to variations of the parameters used in each model.

The best values of $R^{2}$ were 0.9854 and 0.9826 for the Brockamp-Wenner and Albrecht models in BU and TE provinces, respectively.

The provinces of Iran are divided into five categories (at least): the provinces near the Persian Gulf (KH, BU, and HO), the provinces near the Caspian Sea (GI, MZ, and GO), the provinces of the north-east of Iran (WA, EA, AR, and ZA), $\mathrm{CB}$ (due to the different weather conditions than the near provinces), and the other provinces. These categories are useful for future studies over Iran.

We can use the mass transfer-based models for the other regions (in other countries) based on ranges of each weather parameter for the best models with respect to their errors.

Only if we use the mass transfer-based models for suitable and specific weather conditions (based on weather conditions and the categories), the highest preciseness of estimation will be obtained.

\section{References}

1. Xu C-Y, Chen D (2005) Comparison of seven models for estimation of evapotranspiration and groundwater recharge using lysimeter measurement data in Germany. Hydrol Process 19:3717-3734

2. Acheampong PK (1986) Evaluation of potential evapotranspiration methods for Ghana. GeoJournal 12(4):409-415

3. Albrecht F (1950) DieMethoden zur Bestimmung Verdunstung der natürlichen Erdoberfläche. Arch Meteor Geoph Biokl Ser B2:1-38

4. Allen R, Tasumi M, Morse A, Trezza R, Wright J, Bastiaanssen W, Kramber W, Lorite I, Robison C (2007) Satellite-based energy balance for Mapping Evapotranspiration with Internalized Calibration (METRIC) - applications. J Irrig Drain Eng 133(4):395-406

5. Allen RG, Jensen ME, Wright JL, Burman RD (1989) Operational estimates of reference evapotranspiration. Agron J 81(4):650-662
6. Allen RG, Pereira LS, Howell TA, Jensen ME (2011) Evapotranspiration information reporting: I. Factors governing measurement preciseness. Agr. Water Manage 98(6):899-920

7. Al-Sha'lan S, Salih A (1987) Evapotranspiration estimates in extremely arid areas. J Irrig Drain Eng 113(4):565-574

8. Allen RG, Pereira LS, Raes D, Smith M (1998) Crop evapotranspiration. Guidelines for computing crop water requirements. FAO irrigation and drainage. Paper no. 56. FAO, Rome

9. Khoshravesh M, Gholami Sefidkouhi MA, Valipour M (2015) Estimation of reference evapotranspiration using multivariate fractional polynomial, Bayesian regression, and robust regression models in three arid environments. Applied Water Science. doi: 10.1007/s13201-015-0368-x

10. Valipour M, Singh VP (2016) Global experiences on wastewater irrigation: challenges and prospects. In: Maheshwari B, Singh VP, Thoradeniya B (eds) Balanced urban development: options and strategies for liveable cities. AG: Springer, Switzerland, pp. 289327

11. Valipour M, Gholami Sefidkouhi MA, Raeini-Sarjaz M, (2017a) Selecting the best model to estimate potential evapotranspiration with respect to climate change and magnitudes of extreme events. Agricultural Water Management. doi: 10.1016/j.agwat.2016.08.025

12. Valipour M, Gholami Sefidkouhi MA, Khoshravesh M (2017b) Estimation and trend evaluation of reference evapotranspiration in a humid region. Italian Journal of Agrometeorology. In Press.

13. Valipour M (2015a) Future of agricultural water management in Africa. Arch Agron Soil Sci 61(7):907-927

14. Valipour M (2015b) Calibration of mass transfer-based models to predict reference crop evapotranspiration. Applied Water Science. doi: 10.1007/s13201-015-0274-2

15. Valipour M (2015c) Analysis of potential evapotranspiration using limited weather data. Applied Water Science. doi: 10.1007/s13201014-0234-2

16. Valipour M (2015d) Long-term runoff study using SARIMA and ARIMA models in the United States. Meteorol Appl 22(3):592598

17. Valipour M (2013a) Increasing irrigation efficiency by management strategies: cutback and surge irrigation. ARPN Journal of Agricultural and Biological Science. 8(1):35-43

18. Valipour M (2013b) Necessity of irrigated and rainfed agriculture in the world. Irrigation \& Drainage Systems Engineering. S9, e001. $\mathrm{http}$ //omicsgroup.org/journals/necessity-of-irrigated-and-rainfedagriculture-in-the-world-2168-9768.S9-e001.php?aid=12800

19. Valipour M (2013c) Evolution of irrigation-equipped areas as share of cultivated areas. Irrigation \& Drainage Systems Engineering 2(1):e114. doi:10.4172/2168-9768.1000e114

20. Valipour M (2013d) Use of surface water supply index to assessing of water resources management in Colorado and Oregon, US. Advances in Agriculture, Sciences and Engineering Research 3(2):631-640 http://vali-pour.webs.com/13.pdf

21. Valipour M (2012a) Hydro-module determination for Vanaei Village in Eslam Abad Gharb, Iran. ARPN Journal of Agricultural and Biological Science 7(12):968-976

22. Valipour M (2012b) Ability of Box-Jenkins models to estimate of reference potential evapotranspiration (a case study: Mehrabad Synoptic Station, Tehran, Iran). IOSR Journal of Agriculture and Veterinary Science (IOSR-JAVS) 1(5):1-11. doi:10.9790/23800150111

23. Valipour M (2012c) A comparison between horizontal and vertical drainage systems (include pipe drainage, open ditch drainage, and pumped wells) in anisotropic soils. IOSR Journal of Mechanical and Civil Engineering (IOSR-JMCE) 4(1):7-12. doi:10. 9790/1684-0410712

24. Valipour M (2014a) Application of new mass transfer formulae for computation of evapotranspiration. Journal of Applied Water Engineering and Research 2(1):33-46 
25. Brockamp B, Wenner H (1963) Verdunstungsmessungen auf den Steiner See bei Münster. Dt Gewässerkundl Mitt 7:149-154

26. Dalton J (1802) Experimental essays on the constitution of mixed gases; on the force of steam of vapour from waters and other liquids in different temperatures, both in a Torricellian vacuum and in air on evaporation and on the expansion of gases by heat. Mem Manch Lit Philos Soc 5:535-602

27. Mahringer W (1970) Verdunstungsstudien am Neusiedler See. Arch Met Geoph Biokl Ser B 18:1-20

28. Meyer A (1926) Über einige Zusammenhänge zwischen Klima und Boden in Europa. Chemie. der Erde 2:209-347

29. Penman HC (1948) Natural evaporation from open water, bare soil and grass. Proc R Soc Lond Ser A 193:120-145

30. Rohwer C (1931) Evaporation from free water surface. USDA Tech Null 217:1-96

31. Romanenko VA (1961) Computation of the autumn soil moisture using a universal relationship for a large area. In: Proceedings, Ukrainian Hydrometeorological Research Institute, no. 3. Kiev.

32. Trabert W (1896) Neue Beobachtungen über Verdampfungsgeschwindigkeiten. Meteorol Z 13:261-263

33. Papadakis J (1966) Climates of the world and their agricultural potentialities. Buenos Aires: published by author.

34. Bormann H (2011) Sensitivity analysis of 18 different potential evapotranspiration models to observed climatic change at German climate stations. Clim Chang 104(3-4):729-753

35. WMO (1966) Measurement and estimation of evaporation and evapotranspiration. Tech. Pap. (CIMO-Rep) 83. Genf.

36. Azhar A, Perera B (2011) Evaluation of reference evapotranspiration estimation methods under Southeast Australian conditions. J Irrig Drain Eng 137(5):268-279

37. Chiew FHS, Kamaladasa NN, Malano HM, McMahon TA (1995) Penman-Monteith, FAO-24 the potential evapotranspiration and class - a pan data in Australia. Agr. Water Manage 28(1):9-21

38. Estevez J, Gavilan P, Berengena J (2009) Sensitivity analysis of a Penman-Monteith type equation to estimate reference evapotranspiration in southern Spain. Hydrol Process 23:3342-3353

39. Schrader F, Durner W, Fank J, Gebler S, Putz T, Hannes M, Wollschlager U (2013) Estimating precipitation and actual evapotranspiration from precision lysimeter measurements. Procedia Environ Sci 19:543-552

40. Hargreaves G (1989) Preciseness of estimated potential evapotranspiration. J Irrig Drain Eng 115(6):1000-1007

41. Jakimavicius D, Kriauciuniene J, Gailiusis B, Sarauskiene D (2013) Assessment of uncertainty in estimating the evaporation from the Curonian Lagoon. Baltica 26(2):177-186
42. Pirnia MK, Memarian GH (2008) Ranjbar Kermani AM, (Ed.) Stylistics of Iranian architecture, Sorush Danesh, Tehran, Iran. ISBN: 964-96113-2-0. Accessed date 12 June 2008

43. Hamzeh Nezhad M, Rabbani M, Torabi T (2015) The role of wind in human health in Islamic medicine and its effect in layout and structure of Iranian classic towns. Naghsh Jahan 5(1):43-57 In Persian

44. Amiraslani F, Dragovich D (2010) Cross-sectoral and participatory approaches to combating desertification: the Iranian experience. Natur. Resour Forum 34(2):140-154

45. Valipour $\mathrm{M}(2014 \mathrm{~b})$ Use of average data of 181 synoptic stations for estimation of reference crop evapotranspiration by temperaturebased methods. Water Resour Manag 28(12):4237-4255

46. Valipour M, Montazar AA (2012) An evaluation of SWDC and WinSRFR models to optimize of infiltration parameters in furrow irrigation. American Journal of Scientific Research 69:128-142

47. Valipour M (2015e) Temperature analysis of reference evapotranspiration models. Meteorol Appl 22(3):385-394

48. Valipour M (2015f) Evaluation of radiation methods to study potential evapotranspiration of 31 provinces. Meteorol Atmos Phys 127(3):289-303

49. Valipour M, Eslamian S (2014) Analysis of potential evapotranspiration using 11 modified temperature-based models. International Journal of Hydrology Science and Technology 4(3):192-207

50. Sahoo B, Walling I, Deka B, Bhatt B (2012) Standardization of reference evapotranspiration models for a subhumid valley rangeland in the Eastern Himalayas. J Irrig Drain Eng 138(10):880-895

51. Singh VP, Xu CY (1997b) Sensitivity of mass transfer-based evaporation equations to errors in daily and monthly input data. Hydrol Process 11(11):1465-1473

52. Sepaskhah AR (1999) A review on methods for calculating crop evapotranspiration. In Proceeding of the 7th National Conference on Irrigation and Evapotranspiration. Shahid Bahonar University, Kerman, Islamic Republic of Iran. 1-10

53. Fooladmand HR (2008) Evaluation of five methods for monthly evapotranspiration calculation in Shiraz region. J Agr Sci 13(2): 371-379

54. Fooladmand HR (2011) Evaluation of some equations for estimating evapotranspiration in the south of Iran. Archiv. Agron Soil Sci 57(7):741-752

55 Yannopoulos SI, Lyberatos G, Theodossiou N, Li W, Valipour M, Tamburrino A, Angelakis AN (2015) Evolution of water lifting devices (pumps) over the centuries worldwide. Water 7(9):5031-5060 